CLINICA NEURGLógICA DA FACULDADE DE MEDICINA DA UNIVERSIDADE DE SAO PAUlO - Prof. Aderbal Tólosa

\title{
O EXAME NEUROLÓGICO
}

\author{
OSWALDO FREITAS JULIÃO
}

3.० Assistente

A observação neurológica exige tres requisitos preliminarès:

1 - Sistematização do exame - A exploração desordenada e insuficiente das funções do sistema nervoso deixa de revelar, muitas vezes, os elementos justamente de maior importancia para o diagnóstico. Por isso, convem sempre conduzir o exame neurológico em obediência a um plano previamente organizado, onde as diversas ! funçốes sejam pesquisadas em determinada sequência, de acordo com esquema pré-estabelecido. Impõe-se, pois, a sistematização do exame neurológico, pela vantagem de assegurar a. investigação das funções do sistema nervoso sem omitir dados eventualmente elucidativos para o diagnóstico.

2 - Conhecimento preciso da tecnica de exame - E' indispensavel realizar o exame segundo as regras, bem estabelecidas, da propedêtica nervosa, pois os defeitos de tecnica, proporcionando falsos infórmes, acarretam fatalmente diagnósticos errôneos. Assim, por exemplo, admitir a alteração de um reflexo que a pesquisa correta revelará achar-se normal, ou tirar conclusões sobre o estado de uma sensibilidade defeituosamente pesquisada, constituem, sem duvida, pontos de partida para erros de diagnóstico.

3 - Compreensão exata dos fenômenos observados - Para - conveniente aproveitamento dos dados obtidos, exige-se a correta interpretação dos mesmos, o que só se torna possivel mediante o conhecimento de noções basicas de anatomia e fisio-patologia do sistema nervoso. Assim, a verificação de um reflexo abolido ou exagerado, a existência de umạ dissociação da sensibilidade etc... sëriam deștituidas de interesse si não fossem devidamente avaliados quanto ao seu significado. 
O Serviço de Clinica Neurológica da Faculdade de Medicina de São Paulo adota a seguinte sistematização (*), da autoria do Professor Aderbal Tolosa:

IDENTIFICAÇÃO DO PACIENTE: Nome, Idade, Côr, Profissão, Estado civil, Nacionalidade, Residencia, Procedencia. Data do exame.

I - ANAMNESE - Queixa. História da Moléstia Atual. Antecedentes. familiares. ;

II - INSPEÇÃO GERAL - Modo de apresentação. "Habitus". Tipo. Expressão. Tegumentos. Estigmas, etc:

III - EXAME CLÍNICO GERAL - Estado geral. Aparelhos: Circulatório, Respiratório, Digestivo, Genito-Urinário, Endócrino.

IV - EXAME NEUROLOGICO:

1 - Estado psíquico: Mentalidade, inteligência, memória, etc....

2 - Atitude - Facies - Equilíbrio.

3 - Motricidade:

a) Motricidade voluntária: Paralisias e paresias. Força Muscular. Incoordenaçôes. Hipocinesias. - Apraxias.

b) Movimentação passiva: Articulações. Tono muscular.

c) Motricidade automática: Marcha, Fala, Respiração, Deglutição, Mastigação, Mímica, etc.

d) Motricidade involuntária:

A) Espontânea - Hipercinesias. Tremores, coréas, atetoses, caimbras, mioclonias, torsões, espasmos, balismos, tiques, convulsões.

B) Reflexa - Reflexos propriamente ditos (clônicoś, tônicos, simpáticos) ; Clono, Trepidações, Automatismo, Sincinesias.

4 - Sensibilidade: a) Especial (Sensorial) : Visão, Audição, Olfação, Gustação.

b) Geral:

1 - Subjetiva: Dores, parestesias, distúrbios cenêstésicos.

2 -Objetiva: Superficial (Tátil, Dolorosa e Térmica). Profunda (Segmentar, Ossea, Visceral, Dolorosa à pressão profunda, Barestésica, Estereognóstica, localização e Discriminação tátil).

5 - Fenômenos tróficos: musculares, cutâneos, osseos, etc....

6 - Fenômenos vaso motores: edemas, dermografismos, eritemas, asfixias, distermias.

V - EXAMES COMPLEMENTARES - Neuro-Ocular, Neuro-Oto-Laringológico, Radiológico, Liquórico, Elétrico, etc.

VI - SÚMULA - DIAGNOSTICO.

VII - PROGNÓSTICO - TRATAMENTO - EVOLUÇÃO.

\section{I - ANAMNESE}

Facil de obter-se, quando o doente se exprime com espontaneidade e justeza. Limita-se, então, o papel do médico a orientar o

(*) Essa sistematização, além de evitar lapsos na investigação das funções nervosas, encerra o mérito de relacionar, tanto quanto possivel, os sináis observados ao setor comprometido do Sistema Nervoso.

Em seu estudo, procurámos seguir a orientação dada pelo Prof. A. Tolosa no Curso de Neurologia da Faculdade. 
paciente na exposição dos sintomas, tendo, entretanto, o cuidado de evitar sugestões.

Outras vezes, ao contrário, a obtenção da anamnese é dificil, ou mesmo impossivel (alterações da linguagem, distúrbios psíquicos, comas, etc.), tornando-se, então, indispensáveis. as informações da família.

A anamnese será, tanto quanto possivel, minuciosa e completa: Permite apreciarem-se, no doente, o psiquismo, a mímica, a gesticulação, o estado da palavra, etc... e em certos casos, denuncia, imediatamente, o diagnóstico.

a) Queixa - Averiguar quais os principais males que motivaram a consulta. Lembrar, entretanto, que nem sempre a queixa representa o elemento de maior significado para o diagnóstico. Outras vezes, os sintomas nervosos, relacionando-se aos mais diversos aparelhos, tais como perturbações visuais, vómitos, crises viscerais, distúrbios esfinctéricos, etc..., conduzem o doente ao oculista, gastroenterologista e a médicos de outras especialidades, antes de faze-lo comparecer ao neurologista.

b) História da moléstia atual - Apurar quando se iniciou a doença e a maneira pela qual se instalaram os fenômenos mórbidos, si de modo insidioso, como ocorre por exemplo nas afecções de fundo degenerativo, si de modo súbito, conforme se observa em casos filiados a acidentes vasculares (hemorragias, tromboses, embolias). Reconstituir, tanto quanto possivel, a evolução que apresentou o quadro patológico até a data do exame, pela ordem do aparecimento dos sintomas. Às vezes, a afecção evolve sob a forma de surtos, notando-se remissões espontâneas em certos casos (Esclerose em placạs) e, em outros, peoras. Outras vezes, a afecção assume carater progressivo, carater posto em relevo na própria denominação de certas moléstias: Ataxia locomotora progressiva, Distrofia muscular progressiva, Paralisia Geral Progressiva, etc... Em determinados casos, observam-se recidivas (Paralisia periodica de Westphall) ou crises (Histeria, Epilepsia), etc...

Esclarecer quais as medidas terapêticas a que o paciente por ventura já se tenha submetido $\mathrm{e}^{-}$quais os resultados obtidos. Proceder, finalmente, a um "Interrogatório relativo aos diferentes aparelhos", evitando-se, dessa forma que outros quaisquer distúrbios passem despercebidos ao exame.

c) Antecedentes pessoais - Investigar a existência de fatores que possam ter tido influência na gênese da afecção em apreço. Averiguar: as condiçôes de nascimento (encefalopatias infantis, convulsões epileptiformes, deformidades resultantes de traumatismos de parto, nascimentos prematuros, etc.); condições de crescimento (aprendizagem da marcha e fala, despertar da inteligência, etc...); 
moléstias ocorridas na infância (encefalopatias infantis filiadas ao sarampo, varicela, escarlatina, coqueluche; meningites, convulsões, poliomielites, coréas, reumatismo, etc...) e na idade adulta; passado venéreo, sobretudo a existência de sífilis; esclarecida pelas informações sobre o acidente inicial, incidência de abortos, natimortos, prematuros, etc... e responsavel por multiplas manifestaçôes neurológicas (endoarterites, atrofias óticas, sifilis cerebral, tabes, paralisia geral); traumatismos, importantes na determinação de diversas manifestações neurológicas (paralisias periféricas, síndroma de BROWN-SEQUARD, epilepsias traumáticas; etc...); hábitos de vida: vícios e intoxicações, especialmente alcoolismo (polineurites, comprometimento cerebelar, etc...); profissão: intoxicações profissionais (polineurites ocasionadas pelo chumbo, arsênico, mercúrio, manganez, beñzina, etc...), caimbras profissionais (caimbras dos escrivães, dos dactilógrafos, dos telegrafistas, dos pianistas, etc...).

d) Antecedentes familiares - Verificar si os antecedentes do individuo acusam a existência de molestias hereditarias ou familiares do sistema nervo'so. Em alguns casos, é observada Hereditariedade similar (Heredo-ataxia cerebelosa de Pierre-Marie, Mal de Frie= DREICH, Miopatias, Paraplegia espasmódica familial, Coréa de HunTINGTON, Atrofia ótica congênita familial, etc...). Em outros, Herança Dissimilar (Hemiplegias infantis, Síndroma de Little, Atrofia cerebelar, Malformações óssea's, como oxicefalia, microcefalia, espina-bifida e outras, distrofias endócrinas, etc...). Taras neuropáticas tambem podem ser observadas, como consequência de molestias nos antecedentes.

O diagnóstico de determinadas afecções - o da Paraplegia espasmódica de Strumpell, por exemplo - depende, essencialmente, da verificação, no caso em exame, do carater familial. Outras vezes, o diagnóstico decorre do encontro, na familia do paciente ou nas pessoas de sua convivência, de casos declarados da afecção de que se suspeita ser o indivíduo portador. Assim, uma neurite isolada do cubital ou do ciático poplítio externo poderá ser filiada certamente ao Mal de Hansen, si o inquérito demonstrar a existência indiscutivel de Lepra nas pessoas com as quais convive o paciente.

\section{II - EXAME GERAL}

A inspeção geral do doente fornece muitas vezes elementos reveladores de um diagnóstico: atitudes típicas (Meningites, Tétano), atrofias musculares com distribuição caraterística (Miopatias), contrações fibrilares (sofrimento crônico das células das pontas ante- 
riores da medula), hipercinesias (Síndromas do Estriatum, geralmente), amimía (Síndromas do Paleostriatum), paralisias, etc..

A "impressão do conjunto" é,pois, de indiscutivel valor em determinados casos neurológicos. Não nos esqueçamos, porem, que tal impressão, por mais elucidativa que seja para o diagnóstico, não dispensará o exame completo do paciente e nem deve sobrepor-se ao raciocínio clínico.

Áo exame físico geral, serão observados: pele e anexos, mucosas, panículo adiposo, sistema ósseo e musculatura, gânglios, nervos acessiveis à palpação; tipo constitucional, peso, estatura; temperatura; existência de estigmas físicos de degeneraçã̃o (assimetria craniana, microcefalia, macrocefalia, hidrocefalia, etc..) e de estigmas luéticos (ósseos, dentários, cutâneos, etc..).

A facies e atitude, em virtude de sua importância para a diagnose das afeçõos do sistema nervoso, merecem estudo especial, devendo ser analizadas à parte, no "Exame Neurológico propriamente dito.".

\section{III - EXAME CLÍNICO DOS DIFERENTES APARELHOS}

Em vista das íntimas interdependências existentes entre sistema nervoso e demais setores do organismo, impõe-se o exame clínico cuidadoso dos diversos aparelhos da economia, pois ássim poderão ser surpreendidos, em quaisquer orgãos, os mais variados distúrbios ligados ao comprometimento das funções nervosas e vice-versa. Com efeito, as alterações nervosas reconhecem, muitas vezes, como causas:

transtornos circulatórios: hemiplegias consequentes a trombose, em artério-escleróticos, ou a embolia, acidente possivel nos portadores de estenose mitral; comas, determinados por hemorragia cerebral; claudicação intermitente por espasmos vasculares, etc...

anemias, condicionando as Síndromas Neuro-Anêmicas;

tuberculose pulmonar acarretando meningites, Mal de Port e, consequentemente, paraplegias espasmódicas, etc...

tumores malígnos do pulmão, do estômago, da próstata ou de outros orgãos determinando, por metástase, o Cancer vertebral, d'onde a possibilidade de sobrevinda de Compressão medular, etc...

Por outro lado, as desordens do Sistema Nervoso refletem-se, com maior ou menor intensidade, nos mais variados distritos da economia. Na Tabes, por exemplo, observam-se crises gástricas, intestinais, laríngeas, perturbações esfinctéricas, da esfera sexual e outras; nas hipertensões cranianas, vómitos, bradicardia e perturbações oculares; em certas enfermidades do Sistema Extra-Piramidal, tais como na Moléstia de Wilson e na Pseudo-Esclerose de WestphallStrumpell, a cirrose hepática; em Síndromas bulbares, disfagias, dispnéas e perturbaçốes do ritmo circulatório, etc...

A estreita correlação entre o sistema nervoso e o aparelho endócrino se denuncia nos numerosos casos em que, ao lado das disfun- 
ções glandulares, ocorrem distúrbios do âmbito neurológico, salientando-se, nesse sentido, a importância do Diencéfalo, tão merecidamente denominado "cérebro endócrino".

Convem, pois, ter sempre em mente o profundo parentesco entre sistema nervoso e demais aparelhos da vida orgânica. O esquecimento de tal noção tem ocasionado, às vezes, equívocos lamentáveis, como por exemplo a prática de intervenções abdominais em tábidos, portadores de gastralgias.

\section{IV - EXAME DO SISTEMA NERVOSO 1 - EXAME PSIQUIÁTRICO}

Como preliminar, deve o clínico, por meio do exame psíquico (*), inteirar-se das condiçỗes mentais do paciente. Poderá, assim, apurar, no caso em apreço, a existência de dissimulação ou de simulação, quer conciente, quer inconciente (Histeria). Poderá, por outro lado, surpreender desordens psíquicas, tambem comuns em certas afecçôes neurológicas, conforme se observam nos traumatismos cranianos (amnésias, desorientação auto e alopsíquica, etc), na Paralisia Geral (euforia, idéas delirantes de grandeza, distúrbios da memória, etc.), nos tumores cerebrais (estados confusionais) principalmente nos do lobo frontal (moria, desorientação espacial, distúrbios da atenção e carater, etc...), nas encefalopatias infantis (oligofrenias), na artério-esclerose cerebral (dismnésias, puerilismo, alterações do carater, rebaixamento das faculdades mentais), na Coréa de Huntington (distúrbios da conduta, da afetividade, perda dos sentimentos éticos, etc...), na Tabes (psicoses tábidas), nas neuroanemias (Síndromas Neuro-Psico-Anêmicas), na Pelagra, etc...

\section{2 - ATITUdE - FACIES - EQUILfBRIO}

O estudo das grandes funções do Sistema Nervoso - Motricidade, Sensibilidade; Troficidade - deve ser precedido pela apreciação dos dados que, no paciente, se imponham logo à primeira vista, tais como Atitude, Facies e Equilíbrio.

Atitude - A a titude do paciente revela-se, em alguns casos, tão caraterística, a ponto de sugerir imediatamente o diagnóstico. Isto se verifica no Mal de Parkinson e Sindromas Parkinsonianas ("atitude de estátua"), nas Hemiplegias capsulares (flexão do membro superior e extensão do inferior: Atitude de Wernicke-MANN), nas Diplegias cerebrais e especialmente na S. de LitTle (membros inferiores em flexão e rotação interna, joelhos acolados, pés em extensão e afastados um do outro, etc...), nas Paralisias periféricas ("mão pêndula", na neurite do radial, pé "caído", na do ciático-poplítio-

$\left(^{*}\right)$ Para proceder-se ao exame mental, consultar a "Sistematização do Exame Psiquiátrico", da autoria do Dr. JoÄo Carval hal Ribas, nesta revista. 
externo, etc...), nas Miopatias (lordose lombar, pés afastados, amiotrofias com distribuição caraterística, etc...), nas Meningites (rigidez da nuca, atitude em "cão de espingarda" no decúbito lateral), no Tétano (trismo, opistótono, pleurotótono, emprostótono) e em muitas outras afecções.

As atitudes anormais podem resultar de modificações do Tono muscular (visto que a atitude depende, essencialmente, de reflexos de caráter tônico), de paralisias orgânicas e amiotrofias (Poliomielites, radiculites, neurites, miopatias), de espasmos musculares (espasmos de torsão, tétano), de malformações ósseas (Mal de Potr, Espondilose rizomélica), de mecanismo de defesa, antálgico (radiculites, ciáticas, torcicolo, tumores da fossa craniana posterior), etc...

Facies - Tambem a expressão fisionômica do indivíduo, por apresentar-se alterada de maneira caraterística em certas moléstias do Sistema Nervoso, permite, não poucas vezes, o pronto reconhecimento da afecção em apreço.

São caraterísticas: a Facies ou Máscara Parkinsoniana, inexpressiva, imovel, "congelada"; a Facies de Hutchinson, principalmente observada na Tabes, e caraterizada pela oftalmoplegia, ptose palpebral e enrugamento frontal; a Facies da Diplegia Facial, imutavel (Facies "Antonina", da Lepra) ; a Facies na Paralisia Facial unilateral, tipo periférico (maior abertura da fenda palpebral no lado paralisado, lagoftalmo, epífora, apagamento do sulco naso-labial, desvio da boca, etc.), ou central (alterações apenas no território do facial inferior). São ainda típicas: a Facies na Hemi-atrofia e Hemi-hipertrofia facial; na Paralisia Labio-Glosso-Laríngea; a F. coreica, F. atetósica, F. miopática, F. tetânica (riso sardônico), F. Acromegálica, F. Basedowiana, F. mixedematosa, F. esclerodérmica, etc.

Equilíbrio - Será apreciado estando o doente em atitude erecta (equilíbrio estático), ou em marcha (equilíbrio dinâmico).

$\mathrm{Na}$ posição erecta, observar si o doente se mantém firme e imovel ou, ao contrário, apresenta instabilidade do corpo. Nos casos de afecção cerebelar; verifica-se que o doente, afim de manter-se firme, procura alargar a base de sustentação pelo maior afastamento clos pés; pode ser observada a tendência à queda para frente, para traz ou para os lados (Antero, retro e lateropulsões).

Outras vezes, o paciente consegue manter-se firme, ainda que esteja com os pés unidos, sob a condição porem de permanecer com os olhos abertos; oscilações sobrevirão, entretanto, assim que o doente feche os olhos (Sinal de RomberG), encontrado na Tabes, no Mal de Friedreich, nas Ataxias labirínticas, etc. Em casos mais frustos, as oscilações apenas se manifestarão quando o paciente se mantem apoiado sobre um único pé (prova de FoURnIER), ou quando coloca um pé atraz do outro (Sinal de Romberg "sensibilizado"), etc... O verdadeiro Sinal de Romberg não deve ser confundido 
com as oscilações que podem apresentar os indivíduos neuróticos e os simuladores (Pseudo-RomberG).

Os distúrbios do equilíbrio dinâmico evidenciam-se na marcha atáxica do tábido, na ebriosa do cerebelopata, na titubeante do portador de afecção labiríntica, etc.

A impossibilidade de manter-se de pé, Astasia, e de andar, Abasia, pode observar-se nos doentes com afecções do cerebelo ou: vias cerebelares e tambem nos histéricos.

\section{3- MOTRICIDADE}

Não se apresenta sempre sob o mesmo aspecto e depende de diferentes mecanismos. Devem ser encaradas as seguintes modalidades:

a) Motricidade voluntária ou ativa, que o indivíduo realiza de modo conciente, pela ação da vontade. Acha-se sob a dependência do. Sistema Motor Piramidal.

b) Motricidade automática, que se realiza s̄em intervenção da. conciência, embora possa, a qualquer momento, sofrer tambem a sua influência, como ocorre com a marcha, fala, mímica, mastigação, deglutição, respiração e, de modo geral, com todos movimentos automáticos, associados e instintivos. Acha-se subordinada ao Sistema Motor: Extra-Piramidal.

c) Matricidade involuntária, que sempre se realiza sem a participação da vontade: de modo inteiramente espontâneo (Motricidadeinvoluntária espontânéa) ou condicionada a um excitante (Motricidade involuntária provocada ou reflexa). Os movimentos involuntários espontâneos ocorrem, com frequência, em afecções do Sistema Extra-Piramidal. Os movimentos involuntários provocados, ou reflexos, dependem, essencialmente, do Sistema Motor Periférico.

d) O exame da motricidade deve ser completado pela apreciação. do estado das articulações e do Tono muscular, o que se verificará pela Movimentação Passiva, isto é, mediante a execução, por parte do. médico, de movimentos ao nivel dos diversos segmentos do corpo do paciente. Para melhor sistematização do exame, convem proceder-se à movimentação passiva logo em seguida à apreciação da motilidade ativa.

\section{a) MOTRICIDADE VOLUNTÁRIA}

Para pesquiza-la', manda-se o doente executar todos os tipos de movimentos possiveis ao nivel das diferentes articulações. Devem ser apreciadas, na realização desses movimentos; a sua amplitude, energia, coordenação, oportunidade e velocidade.

$E$ ' indispensavel proceder ao exame dos diferentes grupos musculares de maneira sistematizada e, em relação às partes simétricas do. corpo, de modo comparativo. Serão apreciados os seguintes movimentos : 
1 - Movimentos dos membros inferiores - Dedos: flexão e extensão. Articulação tibio-tarsica: flexão, extensão, adução e abdução, rotação dos pés.. Art. do Joelho: flexão e extensão das pernas. Art. coxo-femural: flexão, extensão, adução, abdução e rotação do membro inferior.

2 - Movimentos dos membros superiores - Dedos: flexão, extensão, adução e abdução; oposição do polegar. Art. do punho: flexão, extensão,. adução e abdução, rotação da mão. Art. do cotovelo: flexão, extensão, pronação e supinação do antebraço. Art. escápulo-humeral: flexão, extensão, adução, abdução, rotação do membro superior.

3 - Movimentos do tronco - Flexão, extensão, movimentos de lateralidade, rotação.

4 - Movimentos da cabeça - Movimentos de flexão e torsão da cabeça (Esterno-cleido-mastoideu) ; elevação da omoplata (Trapezio): XIo par craneano, Espinhal.

Movimentos da face (músculos da mímica): enrugamento da fronte, oclu-são palpebral, dilatação das narinas, movimentos da boca, contração do cuticular do pescoço: VII par, Facial.

Movimentos da mastigação: elevação, movimentos de lateralidade e propulsão do maxilar inferior: "Vo par, Trigêmeo.

Movimentos da lingua: XII par, Hipoglosso.

Movimentos do véo do paladar e da deglutição: IXo par, Glosso faríngeo.

Cordas Vocais: n. recurrente ( $X^{o}$ par, Pneumogástrico).

Movimentos Oculares: Elevação da palpebra superior, movimentos do clobo ocular para cima e para dentro (reto superior), para cima e para fora (pequeno oblíquo), horizontalmente para dentro (reto interno), para baixo e para dentro (reto inferior), pupilo-constrição e acomodação (esfinter e. tnúsculos ciliares), $I I I^{\circ}$ par, Óculo-Motor Comum.

Movimentos do globo ocular para fora, horizontalmente (reto externo): VIo par, Oculo-Motor Externo.

Movimentos do globo ocular para baixo e para fora (grande oblíquo): IV $V^{\circ}$ par, Patético.

Provas especiais existem destinadas a revelar o comprometimento dos músculos subordinados aos nervos radial (Teste da continência, do juramento, sinal da matraca, s. do aperto de mão, etc...), cubital (Teste do jornal, prova do leque, sinal da alavanca), mediano (Teste da agulha, da raspagem, sinal do punho, etc...), do ciáticopoplíteo-externo (Prova de Pitres), etc...

Outros testes ainda existem, adequados ao exame mais preciso dos músculos longo supinador, deltoide, grande peitoral, grande dorsal, grande denteado, etc... E' evidente que a interpretação dos... fenômenos observados exige conhecimentos básicos de anatomia e fisiologia dos músculos e nervos.

\section{PERTUURBAC̨ÕES DA MOTRICIDADE VOLUNTÁRIA}

Paralisias e paresias - A impossibilidade de executar mo-vimentos voluntários constitue a paralisia e a dificuldade aperias em. realiza-los, a paresia.

Conforme a sua distribuição, as paralisias classificam-se em:

1 - Monoplegias, quando a paralisia atinge um único segmento corporal. (monoplegia crural, braquial, facial); 
2 - Paraptegias, quando a paralisia, resultante de causa única, acomete segmentos simétricos (Paraplegia crural, braquial, facial);

3 - Hemiplegias, quando são atingidos os membros do mesmo ladō, direito ou esquerdo;

4 - Tri e Tetraplegias, quando uma única lesão (traumatismo da medula cervical alta, processos do Tronco Encefálico) acarreta a paralisia simultânea de tres ou quatro membros, respetivamente;

5 - Diplegias, quando ocorrem paralisias em segmentos simétricos do corpo, instaladas em ocásiões diferentes por dependerem de causas diversas. Serve de exemplo a diplegia dos pseudo-bulbares, em que o estabelecimento sucessivo de focos múltiplos de amolecimento cerebral acarreta o aparecimento de hemiplegia, a princípio de um lado e, posteriormente, do outro; realiza-se pois, nesses casos, uma soma de duas hemiplegias. Outro exemplo, relativamente frequente, é o da Diplegia Facial.

Sob o ponto de vista clínico, as paralisias classificam-se em flácidas e espasmódicas. As primeiras, geralmente dependentes de lesão do neurônio motor periférico, constituem as verdadeiras paralisias, porisso que se acham sacrificadas todas as formas de motricidade; traduzem-se por hipotonia muscular, arreflexia e amiotrofias, na maioria das vezes acompanhadas de alterações elétricas. As paralisias espasmódicas, que ocorrem nas lesões do neurônio motor central (via piramidal), caraterizam-se, ao contrário das flácidas, por hipertonia muscular, hiper-reflexia profunda e presença do Sinal de BABINSKY.

Contratura - Quando um ou vários músculos do organismo, em virtude de um exagero gráo de hipertonia, assume determinada atitude, permanentemente, dizemos tratar-se de contratura. Esta não deve ser confundida com as retrações ou falsas contraturas, condicionadas por lesões tendinosas, articulares ósseas, etc....

Força muscular - Avalia-se grosseiramente a energia com que se realisam os movimentos voluntários, mandando o doente fazer movimentos e opondo-se à execuçãó dos mesmos. $\mathrm{O}$ exame será feito de modo ordenado e comparativo, segmento por segmento. A dinamometria dará informações mais precisas acerca das alterações da força muscular.

São sobretudo as afecções do sistema motor periférico que acarretam distúrbios da Força Muscular. Constitue, mesmo, o comportamento da força muscular elemento de grande valor na diagnose diferencial entre a polineurite e a tabes, uma vez que se apresenta diminuida, ou abolida, na primeira e conservada na última.

Manobras deficitárias - São de grande utilidade principalmente para a demonstração de paresias pouco acentuadas, dependentes de lesão piramidal (Síndroma deficitária piramidal). Servem, por conseguinte, para estabelecer a distinção entre as paralisias orgânicas e as funcionais.

As provas deficitárias mais importantes são: (*)'

1 - Manobra de Mingazzini - Doente em decúbito dorsal; coxas dispostas verticalmente e fletidas sobre a bacia, em angulo de $90^{\circ}$; pernas tambem fletidas sobre as coxas em angulo reto. Normalmente, o indivíduo mantem essa posição, sem dificuldade, durante algum tempo. Nos casos de lesão da via motora podem-se

$\left(^{*}\right)$ Consultar: "Desdobramento do Síndromo Piramidal". - Prof. A. Tolosa. Ánais Faulistas de Médicina e Cirurgia, Setembro de 1938. 
observar: queda isolada da perna (deficit dos músculos da face anterior da coxa), ou queda isolada da coxa (deficit do psoas: "manobra do psoas"), ou queda simultânea da perna e da coxa (deficit da musculatura da face anterior da coxa e do psoas).

2 - Manobra de Barré - Doente em decúbito ventral; pernas fletidas sobre as coxas, en angulo reto. Esta posição, mantida por alguns minutos sem maior esforço, não persiste si houver deficit dos músculos flexores das pernas. Em consequência, queda deste segmento.

3 - Manobra do pé - Doente em decúbito dorsal, com os membros inferiores em extensão, pés em posição vertical. No caso de haver deficit dos músculos rotadores internos da coxa, produz-se a queda, para fora, do pé (pé em abdução, "pé de cadaver").

4 - Manobra de Raimiste - Doente em decúbito dorsal, antebraços fletidos em angulo reto sobre os braços e mãos dispostas verticalmente, como os antebraços. Conforme o grupo muscular afetado, pode observar-se queda, para fora ou para dentro, do antebraço, da mão ou apenas dos dedos.

Incoordenações - As desordens da coordenação dos movimentos constituem as ataxias. Distinguem-se: a ataxia estática, consequência de alteraçốes da sinergia dos músculos que intervem na manutenção da atitude erecta, e a ataxia dinâmica, verificada no momento da execução de movimentos voluntários. Os movimentos atáxicos, observados principalmente nas afecções que comprome tem as vias da sensibilidade profunda ou as vias cerebelares, realizam-se de modo desordenado e impreciso, denunciando, predominantemente, ora erros na direção, ora erros na medida do movimento.

Verifica-se a ataxia dinâmica mediante certas provas, que devem ser praticadas de um e outro lado do corpo, estando o doente a prinć́pio com os olhos abertos e depois com os olhos fechados; será apreciada a execução dos movimentos realizados de modo rápido e ainda de modo vagaroso. As provas habitualmente usadas são ạs seguintes :

Nos membros superiores: manda-se o doente tocar, com a extremidade do dedo indicador, a ponta do nariz (prova index-nariz), ou o lóbulo da orelha do lado oposto; que ponha em contacto as extremidades dos dedos indicadores estando, inicialmente, com os braços abertos (prova index-index); que realise certos movimentos delicados, tais como: abotoar-se, escrever, enfiar agulha, apreender entre os dedos um pequeno objeto, colocado de preferência em superfície lisa; fazer, com o dedo indicador, contornos de letras, ou números, no espaço, etc...

Nos membros inferiores: manda-se o doente pôr o calcanhar sobre o joelho e depois deslisa-lo sobre a crista da tíbia (prova calcanhar-joelho); elevar o pé a certa altura dọ leito, de maneira a 
tocar a mão do médico; que mantenha os membros inferiores estendidos e elevados a certa altura do leito, verificando-se o aparecimento, ou não, de oscilações, etc...

Os movimentos atáxicos do tronco e da face são mais raramente observados.

A ataxia estática pode ser evidenciada pelo Sinal de Romberg, já mencionado.

Podem-se classificar as ataxias em: 1) tipo sensitivo; 2) tipo cerebelar; 3) tipo sensitivo-cerebelar ou mixto; 4) tipo labiríntico.

I - A ataxia tipo sensitivo, a verdadeira ataxia, observa-se essencialmente na Tabes, caraterisando-se: a) pelo predomínio do erro na direção; b) por agravar-se com a oclusão das palpebras; c) por acompanhar-se do Sinal de RomberG.

$\mathrm{Na}$ Tabes, devido ao comprometimento da sensibilidade profunda conciente, determinado pela degeneração dos cordões posteriores da medula, o doente deixa de receber as impressõs proprioceptivas, que normalmente informam sobre os atitudes segmentares. Daí necessitar o tábido recorrer à visão para corrigir os seus movimentos desordenados e mal dirigidos. A marcha, por exemplo, se faz sob a fiscalização permanente do olhar, denunciando-se ou agravando-se a ataxia quando o paciente faz a oclusão das palpebras ou caminha na obscuridade. Pelo mesmo motivo, o Sinal de Romberg aparece na Tabes.

As ataxias latentes e incipientes podem ser evidenciadas por meio das Manobras de FouRnIER: sob o comando do médico, o doente deverá levantar-se imediatamente de uma cadeira e andar, podendo manifestar-se, então, oscilações do corpo; depois, a uma nova ordem, deverá deter-se no mesmo instante, podendo tambem sobrevir inclinação do corpo; finalmente, estando o doente em marcha, por nova determinação deverá realizar "meia-volta", podendo ainda assim se acusarem oscilações e mesmo esboço de queda. As ataxias discretas tambem se evidenciam muitas vezes, no ato do tábido subir ou principalmente ao descer uma escada.

A ataxia de tipo sensitivo ocorre não só na Tabes, mas em outras afecções: periféricas (polineurites graves, radiculites, neurite intersticial hipertrófica, neuro-tabes periférica, etc.), em afecções medulares (escleroses combinadas - neuro-anemias -, sifilis medular, etc.), em afecções do Istmo do Encéfalo (certas sindromas bulbares, protuberanciais e pedunculares), em determinadas afecções talâmicas e corticais.

II - A ataxia de tipo cerebelar observa-se nas lesões do cerebelo - orgão central da coordenação dos movimentos - ou das vias cerebelares, caraterizando-se pelos seguintes elementos: a) predomínio do erro na medida do movimento (dismetria); b) não ser influenciada pelo controle visual, manifestando-se com a mesma intensidade, quer esteja o doente com os olhos abertos ou fechados; c) não ser acompanhada do Sinal de RomberG.

A incoordenação cerebelar resulta essencialmente da ação de dois fatores: dismetria e assinergia.

As perturbações da medida dos movimentos, ou Dismetrias, conpreendem as hipermetrias e as hipometrias. Então, as provas indexnariz e calcanhar-joelho, sobretudo quando realizadas rapidamente, processam-se sem harmonia, imperfeitamente, acusando erros na me- 
dida e na intensidade dos movimentos. Às vezes, o objetivo visado não chega a ser atingido (hipometria) e, outras vezes, alcançado com violencia ou mesmo ultrapassado (hipermetria). Outros meios reveladores de dismetria são: a prova do copo d'agua, a dos traços paralelos, a da escrita, a da resistência ou de Stewart-Holmes, a do index ou de BARANY, etc...

Presidindo o cerebelo à coordenação dos movimentos simultâneos que contribuem para a execução de quaisquer atos (Sinergia muscular), as lesões daquele orgão acarretam habitualmente distúrbios da referida função. Surge, em consequncia, a asinergia, que pode ser evidenciada pelas seguintes manobras:

a) Prova de Babinsky, que denota a asinergia entre a musculatura do tronco e dos membros inferiores (doente em posição erecta, ao inclinar a cabeça e tronco fortemente para traz, não realiza, ao contrário do indivíduo normal, o movimento compensador de dobrar os joelhos e, em consequência, tende a cair).

b) Inclinar para traz, de surpreza, a cadeira onde esteja sentado o paciente, observando-se assim si o indivíduo; ao contrário do normal, deixa de realizar o movimento compensador da curvatura do tronco para deante ("Prova da cadeira").

c) O doente, em decúbito dorsal e de braços cruzados, tentando sentar-se' no leito, não o conseguirá, produzindo-se, então, a flexão das coxas e a elevação dos pés.

d) A asinergia se traduz ainda pela decomposição dos movimentos, que pode ser apreciada pelas provas index-nariz, calcanharjoelho, calcanhar-nádega, ao colocar o pé sobre uma cadeira, etc. Então, os movimentos não mais se processam associadamente, de maneira harmonica, porem de modo fracionado, com resaltos, em virtude de não se produzirem oportunamente as contrações musculares necessárias ao ato.

$A$ associação da asinergia à dismetria ainda explica certas manifestações próprias das síndromas cerebelares, tais como a adiadococinésia, os distúrbios da palavra e do equilíbrio.

A adiadococinésia, ou disdiadococinésia, é a impossibilidade da execução de movimentos voluntários antagônicos, alternativos, sucessivos e rápidos. Essa impossibilidade, mais nítida nos membros superiores, pode ser surpreendida por manobra simples, em que se realizam rapidamente movimentos opostos, tais como a pronação e supinação das mãos ("faire les marionettes"), ou o seu fechamento e abertura, ou ainda a flexão e extensão do ante-braço sobre o braço.

A palavra nos cerebelopatas mostra-se monótona e explosiva, "escandida".

As perturbações do equilíbrio referem-se ao equilíbrio estático (aumento da base de sustentação; ântero, látero e retropulsões; astasia) e ao equilíbrio dinâmico (marcha ebriosa; abasia). 
III - A ataxia do tipo mixto encerra, ao mesmo tempo, caracteres das incoordenações sensitiva e cerebelar. E' observada por exemplo, nas lesões associadas dos cordões posteriores e dos feixes espinocerebelares ( $\mathrm{Mal}$ de Friedreich, Heredo-ataxia cerebelosa de PierreMarie, etc.).

IV - A ataxia labirintica, dependente de lesões do aparelho e do nervo vestibular, traduz-se por perturbações do equilíbrio estático e da marcha' análogas às da ataxia cerebelar. Diferencia-se, entretanto, desta última pelos seguintes elementos: 1) é acompanhada do Sinal de Romberg; 2) ausência de dismetria, asinergia, adiadococinésia; 3) as variações da posição da cabeça agravam os distúrbios do equilíbrio, motivo pelo qual o paciente, durante a marcha, esforça-se por manter imovel a cabeça; 4) acompanha-se dos demais elementos próprios da síndroma labiríntica, especialmente da. Vertigem de Meniere.

Velocidade dos movimentos - Nos doentes portadores de certas síndromas extra-piramidais (Síndromas palidais), nota-se falta. de espontaneidade nos movimentos, que se executam com dificuldade e vagarosamente. E' a denominada Bradicinesia ou Hipocinesia.

Apraxias (*) - Como apêndice ao exame da Motricidade Voluntária, podemos considerar as apraxias, que se caraterizam pela impossibilidade que apresenta o doente de realizar corretamente os movimentos elementares necessários à execução de atos comuns. $\mathrm{O}$ apráxico perde a memoria dos movimentos necessários à realização. de um ato ou gesto. Assim, é incapaz de fazer com precisão um. cumprimento, uma continência, o sinal da cruz, ou servir-se de uma tesoura ou de um garfo, etc.. Apezar de antigo fumante, não saberá mais servir-se do cigarro, uma vez que não consegue realizar, na devida sequência, os movimentos componentes do ato (prova do cigarro). E' importante lembrar que o apráxico nã̃o é um paralítico, nem atáxico, nem psicopata.

A apraxia ocorre em certas lesões do lobo parietal e do corpo caloso. O centro eupráxico, localizado no lobo parietal esquerdo, age diretamente sobre a circumvolução frontal ascendente do mesmo lado e, por intermédio de fibras que atravessam o corpo caloso, age indiretamente sobre a circumvolução frontal ascendente direita. Dessa forma, o centro eupráxico preside à execução correta dos átos de ambos os lados do corpo, exercendo naturalmente a sua influência atravez das fibras piramidais. Em consequência, lesões graves do lobo parietal esquerdo, destruindo o centro eupráxico, determinarão apraxia bilateral, emquanto que lesões do corpo caloso apenas poderão produzir apraxia unilateral esquerda. E' pois, desnecessario frizar que a pesquisa. da apraxia deve ser praticada separadamente em cada lado do corpo.

$\left({ }^{*}\right)$ Embora colocada no capitulo da Motricidade Voluntária, a apraxia não se refere propriamente à alteração de movimentos ativos, mas a desordens na execuçāo de atos.- 


\section{b) MOVIMENTAÇÃO PASSIVA}

Achando-se o doente, de preferência, em decúbito dorsal, o médico praticará movimentos passivos ao nivel das diferentes articulações, examinando, assim, segmento por segmento do corpo. Apreciará, dessa forma:

1) - O estado das articulações - Investigar a existência de deformações, anquilose, edema, estalidos, etc.. Nos casos em que os movimentos são limitados, distinguir si tal fato decorre de processo articular, de retrações fibro-tendinosas ou de comprometimento do sistema nervoso.

2 - O Tono muscular (estado de semicontração permànente em que se encontram, nas condições normais, os músculos) - Em condições patológicas, pode apresentar-se aumentado (Hipertonia) ou diminuido (Hipotonia), podendo ser avaliado por meio dá inspeção, palpação, movimentação e balanço passivos.

À inspeção, notar o relevo dos.músculos: nítido, exagerado ( $\mathrm{Hi}$ pertonia) ou diminuido, apagado (Hipotonia), com depressões anormais.

À palpação, verificar si as massas musculares se apresentam endurecidas (Hipertonia) ou flácidas (Hipotonia).

À movimentação passiva, apreciar si os movimentos são limitados, oferecendo resistência acima da normal (Hipertonia), ou são movimentos amplos, opondo fraca resistência (Hipotonia).

A movimentação passiva permite verificar, nas meningites, a hipertonia dos músculos cervicais posteriores (rigidez da nuca) e a. hipertonia dos flexores das pernas (pela pesquiza do Sinal de KERNIG).

Balanço passivo das articulações: pratica-lo ao nivel das articulações dos punhos e tornozelos, podendo verificar-se movimentos amplos respetivamente das mãos e dos pés (Hipotonia) ou, ao contrário, ausência de quaisquer oscilações, apresentando-se então como que peças soldadas, a mão e o antebraço, ou o pé e a* perna (Hipertonia). Tambem a rotação passiva do tronco, praticada de modo rápido, estando o doente em atitude erecta, pode revelar, em certos casos, oscilações dos membros superiores (Hipotonia), e, em outros, ausência dos referidos movimentos (Hipertonia). $\mathrm{O}$ carater pendular com que se apresentam às vezes, certos reflexos (patelar, tricipital) denuncia, ainda, a existencia de hipotonia muscular.

\section{ALTERAÇÕES DO TONO MUSCULAR}

1 - Hipotonia - Ocorre nas lesões do neurônio motor periférico (neurites, polineurites, plexites, radiculites anteriores, poliomielites), na Tabes, no Mal de FrIEDREICH, nas secções transversas da medula, nas cerebelopatias, nas síndromas do Estriatum (sindromas hipercinetico-hipotônicas), em certas en- 
cefalopatias, na Amiotonia congenita de OpPEn fieim, nas miopatias, etc.... A hipotonia pode ser ainda congènta, constitucional e desenvolver-se pelo exercício, como nos acrobatas, dansarinos, etc....

2 - Hipertonia - Produzida geralmente pela libertação dos centros tónígenos, em consequência de lesões piramidais ou extra-piramidais.

A hipertonia piramidal, observada nas hemiplegias orgânicas, Esclerose em placas, Esclerose Lateral Amiotrófica, mielites, compressões medulares, Síndroma de LITTLE, etc. apresenta os seguintes caracteres:

a) predomina em certos grupos musculares (flexores no membro superior, extensores no m. inferior);

b) é variavel, não uniforme, aparecendo por paroxismos (visto como se acha intimamente subordinada a um mecanismo reflexo);

c) não apresenta, ao contrario da hipertonia extrapiramidal, o (arater plástico: terminada a movimentação passiva, o segmento examinado, em virtude da contratura, volta imediatamente à atitude anterior;

d) acompanhha-se da exaltação dos reflexos profundos.

A hipertonia ou Rigidez extrapiramidal, observada nas afecções que comprometem o Paleostriatum-Síndromas hipocinetico-hipertônicas (Síndromas Parkinsonianas, Mal de PARKINSON), Degenerações hepato-lenticulares (Molestia de Wilson, Pseudo-Esclerose de WestPhall-Strumpell) - carateriza-se felos seguintes elementos:

a) é global, não tendo preferência para flexores ou extensores, agonistas ou antagonistas;

b) é permanente: a resistencia que oferece à movimentação passiva é sempre a mesma, uniforme, tendo sido comparada, por esse motivo; à "flexibilidade cerea";

c) é uma hipertonia plástica: conserva as atitudes que lhe são impostas ("Rigidez plástica de fixação");

d) acompanha-se do exagero dos reflexos de postura e do fenômeno da tróclea (roda dentada).

Hipertonias transitorias: podem ocorrer em certas infecções (Tétano, Meningites, Raiva, Tetania), intoxicações (pela Estricnina, Ergotina) e perturbações metabólicas.

3 - Tono Alternante - Em determinados casos, no mèsmo doente podem ser observadas hipertonia e hipotonia; assim, na Síndroma de Foerster verifica-se hipertonia quando o doente se encontra na posição vertical e hipotonia quando em decubito.

\section{c) MOTRICIDADE AUTOMÁTICA}

Abrange o estudo da marcha, fala, mímica, mastigação, deglutição, respiração, etc..

Marcha - O exame da marcha será praticado em lugar suficientemente amplo, estando o paciente, de preferência, despido. O doente deverá caminhà em linha reta, numa direção fixa, apreciando-se, assim, a existệncia de desvios ou tendência à queda (ântero, retro e láteropulsões). Requerem observação minuciosa: a maneira do doente colocar o pé no solo (marcha calcaneante do tábido, marcha escarvante do polineurítico), as dimensões dos passos, (m. em passos miudos, dos Pseudobulbares), o comportamento dos membros superiores durante a marcha (movimentos associados da articulação escápulo-humeral não observados nas Síndromas Pali- 
dais), a influência da visão: (o controle visual sendo indispensavel ao tábido) a atitude da cabeça (imovel, nos labirínticos) e do tronco (rígido, nos Parkinsoneanos; com oscilações laterais nos miopáti$\cos )$, etc...

Müitas vezes, ós distúrbios só se evidenciam pela marcha rápida ou lenta, pela marcha lateral, ou ao andar para traz, ou com os olhos fechados, ao subir escadas; ou pelas manobras de Fournier; etc...

As perțurbações da marcha podem ser uni ou bilaterais, do tipo flácido ou espasmódico, dé carater tônico ou clônico, etc..

Principais tipos de marcha: $\mathrm{m}$. ceifante, ou helicópode, nas $\mathrm{He}-$ miplegias piramidais; m. espasmódica, nas Mielites, Esclerose em placas, Esclerọse Lateral Amiotrófica, etc.; m. em pequenos passos, nós Pseudo-bulbares; $m$. parkinsoneana, nas Sindromas Parkinsoneanas ; $m$. coreíca, nas Coréas ; $m$. ebriosa, nas Cerebelopatias; $m$. atá= xica e calcaneante, nas Tabes; m. escarvante, ou em "steppage", nas neurites isoladas do ciático-poplíteo-externo e Polineurites; m. miopática, ou anserina, nas Distrofias Musculares Progressivas; $m$. anfálğica, nas radiculites, ciática, certas neurites, afecções articulares dos membros inferiores, etc.; m. com claudicação intermitente nos casos de arterite obliterante, etc...

Fala - As desordens da fala podem resultar da alteração de qualquer das funções que intervêm na produção da palavra oral: respiração, fonação e articulação.

a) As alterações da palavra por distúrbios da respiração Dispneumias - são condicionadas, mais frequentemente, pela insuficiente inspiração, brusca e demasiado curta; outras vezes trata-se de máu aproveitamento do ar expirado. As dislalias então observadas acham-se, muitas vezes, relacionadas a disfunções vegetativas.

b) As modificações da palavra por desordens da fonação Disfonias e Afonias, respetivamente dificuldade e impossibilidade da produção do som - são determinadas pela paralisia de uma ou ambas as cordas. vocais, por comprometimento do nervo recurrente em casos de tumores do mediastino (por exemplo, aneurisma da crossà da aorta; tumores do esôfago), da tireoide, etc.. Em consequência do comprometimento dos músculos fonadores, a voz, nas disfonias, sofre modificação do timbre, tornando-se, às vezes, monótona, grave e, em outras vezes, bitonal.

c) O's transtornos da palavra por distúrbios da sua articulação - Disartrias e Anartrias, respetivamente dificuldade e impossibilidade de articular a palavra - dependem do comprometimento de qualquer dos grupos musculares que normalmente intervền na artieulação dos sons (músculos do véo do palato, da lingua, dos lábios, masséteres, bucinadores, etc.).

As disartrias podem resultar: 1) de lesões nucleares e infra-nucleares; 2) de lesões supra-nucleares; 3) da ataxia dos orgãos da linguagem. 
1 - Lesões Nucleares e Infra-Nucleares: As lesões nucleares, que comprometem os nucleos motores dos nervos bulbares e protuberanciais (XII, XI, X, IX, VII e V), ocorrem nas Polioencefalites inferiores, na Paralisia LabioGlosso-Laríngea, Esclerose Lateral Amiotrófica, Siringobulbia, etc.. As lesões infra-nucleares, que comprometem a porção propriamente periférica dos referidos pares cranianos, encontram-se nas intoxicações, infecções, traumatismos, neurites em geral.

As disartrias resultantes da lesão isolada dos mencionados nervos, acarretando a paralisia de determinados músculos ,apresentam caracteres mais out menos especiais. Assim, por exemplo:

Lesão do Hipoglosso (XII) : paralisia da lingua, na metade correspondente. Dificuldade em pronunciar as linguais.

Lesão do Pneumo-gástrico (X) e do Glosso-Faríngeo (IX): paralisia do véo do palato e em consequência, voz fanhosa e anasalada. (Rinolalia) e dificuldade em pronunciar os sons guturais.

Lesão do Facial (VII) : paralisia dos músculos dos lábios, bucinadores, etc. Disartria tipo labial, devido à dificuldade em pronunciar as labiais.

Lesão do Trigêmeo(V) : paralisia dos músculos mastigadores (masséteres, temporais, pterigoideus). Dificuldade em pronunciar as dentais.

Nos casos de serem múltiplas as lesões dos nervos cranianos, como sucede nas Polineurites cranianas e nas Polioencefalites, a articulação da palavra torna-se extraordinariamente dificil e penosa, podendo ocorrer completa anartria.

Alterações da articulação da palavra podem ainda surgir nas afecções musculares; assim, na miopatia facio-escápulo-humeral de LANDOUZY-DEJERINE, ha dificuldade sobretudo na pronúncia das consoantes e, nas formas graves da Miastenia de Erb-Goldflam, a articulação da palavra se apresenta tanto mais comprometida quanto maior for o gráo da fadiga muscular, caraterística da afecção, voltando a normalizar-se com o repouso.

2 - Lesões supra-nucleares: As lesões supra-nucleares, que comprometem frequentemente os neuronios córtico-nucleares, ocorrem em diversas circunstâncias, como por exemplo, em consequência de acidentes vasculares: amolecimentos do Hemisfério esquerdo determinando afasia. Regredindo esta ultima, podem-se observar alterações da fala, que se torna indistinta e, muitas vezes, acompanhada da repetição frequente de determinadas palavras, sílabas. ou letras (Palilalia).

Nos Pseudo-Bulbares, observam-se modificações da fala semelhante aquelas da Paralisia bulbar, tornando-se a voz confusa, grave e, às vezes, anasalada.

$\mathrm{Na}$ Paralisia Geral, a disartria, o "sinal fatal" da afecção, carateriza-se particularmente pela dificuldade em articular as labiais, linguais e dentais, e pelo fato do doente suprimir ou deslocar sílabas e empregar termos inadequados.

,Nos Parkinsonianos, a palavra é dificil, monótona, muitas vezes confusa e precipitada no final das frases (taquifemia).

$\mathrm{Na}$ Coréa e Atetose dupla, os movimentos involuntários espontâneos dos músculos respiratórios, da lingua e da face tornam a palavra muitas vezes confusa, interrompida e hesitante.

3 - Ataxia dos orgãos da linguagem - Em certos casos, os distúrbios da palavra decorrem não de paralisias, mas da incoordenação na articulação da. palavra. Assim, nas síndromas cerebelares e, particularmente, na Esclerose em: placas, a palavra é lenta (Bradilalia) ,monótona, frequentemente entrecortada, explosiva (palavra "escandida"). Esse mesmo carater monótono, irregular, da palavra é encontrado na Molestia de Friedreich, na Heredo-ataxia cerebelosa de Pierre-Marie, na Neurite Intersticial Hipertrófica etc.

Também em certos casos de Tabes (forma bulbar) a palavra pode apresentar-se alterada em consequência da ataxia da lingua ou dos músculos fonadores. 
$\mathrm{Na}$ semiologia da fala, merecem ainda particular menção os distúrbios decorrentes exclusivamente do comprometimento ṕsíquico, tais como a logorréa, a coprolália, etc... O mutismo, observado em diversas psicopatias e particularmente na Histeria, não deve ser confundido com as afonias e anartrias, que ocorrem nas eventualidades já referidas.

Perturbações da pronúncia - A pronúncia vịciosa de determinadas consoantes ou sílabas pode ocorrer em casos de malformações congênitas ou adquiridas dos labios, lingua, dentes, palato, afecções nasais, vegetações aḍenoides, etc..

As perturbações da articulação e da pronúncia da palavra já se revelam, na maioria das vezes, à anamnese; outras vezes evidenciam-se melhor por meio da leitura em voz alta ou, como se faz mais frequentemente, por meio de palavras de prova ("tresentos $\mathrm{e}$ trinta e três artilheiros de artilharia, paralelepípedo, ministro plenipotenciário", etc.).

Perturbações da linguagem - Afasias - A afasia é a supressão, ou a alteração da linguagem devida à perda da memoria dos sinais falados ou escritos que nos permitem trocar idéas com nossos semelhantes (P. Stewart). Decorre de lesões assestadas nos centros corticais da linguagem, conservando-se íntegros os músculos que intervêm na articulação da palavra. Processos vașculares cerebrais (hemorragias, tromboses, embolias, espasmos vasculares, etc.)., tumores e abcessos do cérebro, traumatismos crânio-encefálicos são, na maior parte das vezes, as causas responsaveis pelo aparecimento das afasias.

O exame do doente, procedido de acordo com tecnica especial, pernitirá distinguir si se trata de Afasia Sensorial, de Compreensão (cegueira verbal, surdez verbal), ou Afasia Motora, Afasia de Expressão (Afemia, Agrafia).

Mímica - A mímica voluntária, emocional e reflexa podem apresentar-se alteradas, respetivamente nas lesões das vias piramidais, extrapiramidais e periféricas. Nas Síndromas Palidais, observa-se hipomimia e, nas Síndromas do Neo-Striatum, hipermimia. Nos Pseudobulbares, são frequentes as crises de chôro e riso espasmódicos.

Mastigação, deglutição, respiração - Suas perturbações podem ocorrer tanto em afecções centrais como periféricas.

\section{a) MOTRICIDADE INVOLUNTÁRIA}

Compreende a Motricidade Involuntária Espontânea, independente de qualquer excitante, e a Motricidade Involuntária Reflexa, ou provocada. 
Motricidade involuntária espontânea - Os movimentos involuntários espontâneos, que recebem a designação geral de " $\mathrm{Hi}$ percinesias", são movimentos inuteis, parasitas, incoerciveis, principalmente observados nas afecções extrapiramidais (Coréas, Atetoses, Torsões, Balismos, Mioclonias, etc..). Apresentam, como carater comum, o fato de se acentuarem pela ação e emoção e diminuirem com o repouso, podendo mesmo desaparecer completamente durante o sono. E' ainda obscura a físiopatologia de muitos desses movimentos involuntários. Os seus principais tipos são os seguintes: movimentos coréicos (rápidos e bruscos, desordenados, geralmente de grande amplitude, frequentes nos membros, face e lingua), atetósicos (movimentos lentos, de "reptação", irregulares e contínuos, manifestando-se principalmente ao nivel dos dedos e articulação do punho), tremores (oscilações geralmente rítmicas e pouco extensas, aparecendo no repouso - tremor parkinsoneano, por exemplo - ou durante os movimentos, como o tremor "intencional" dos cerebelopatas; são de varios tipos, entre os quais o tremor tóxico - intoxicações pelo alcool, nicòtina, chumbo, arsenico, mercurio, etc., tremor parkinsoneano, tremor "intencional", tremor senil, tremor hereditario, tremor histerico, etc...), mioclonias (abalos rápidos, bruscos, localizados em um ou diversos grupos musculares, podendo persistir durante o sono), balismos (movimentos ritmados, mais amplos e mais lentos que os coreicos, processando-se ao nivel das grandes articulações, como escápulo-humeral e coxo-femural), tiques (movimentos re-, petidos e geralmente restritos, encontrados principalmente em indivíduos psicoastênicos), espasmos, caimbras, convulsões, etc...

Motricidade involuntária reflexa - Considera-se como "áto reflexo" toda transformação de uma excitação sensitiva em efeito motor, operada sem participação da vontade do individuo. $\mathrm{O}$ movimento reflexo é sempre um movimento provocado, em resposta a uma excitação. Assim se podem classificar as diversas manifestações da motricidade involuntaria provocada: Reflexos propriamente ditos, clono, trepidações, automatismos e sincinesias.

A) Reflexos propriamente ditos - Os reflexos habitualmente pesquisados em semiótica nervosa podem ser distribuidos em tres grupos: 1) Reflexos clônicos; 2) Reflexos tônicos; 3) Reflexos simpáticos.

1 - Os reflexjos clônicos, isto é, aqueles que determinam como resposta uma contração muscular brusca e rápida, compreendem os reflexos profundos (tendinosos e ósteo-periósteos) e os superficiais (cutâneos e mucosos). Ver, a proposito, os quadros 1 e 2 . A técnica de pesquisa desses reflexos deve ser perfeita: exploração cuicladosa, metódica e comparativa; região a examinar descoberta. Doente despreocupado, musculatura relaxada; em certos casos, isto só será conseguido graças a manobras especiais (Manobras de JENDRAssik, de LAUfENHAUER, etc...), que têm por finalidade distrair o paciente. 
Atitude do doente favoravel ao exame,havendo uma "posição ótima" para a pesquisa de cada reflexo. O reflexo "idio-muscular" - no qual a contração é obtida pela percussão direta do corpo muscular permitirá avaliar si é correta a posição em que se encontra o doente.

Alterações dos reflexos profundos: a) Variações qualitativas: Os reflexos podem apresentar-se com o carater pendular (casos de hipotonia muscular), com o carater policinético (nas Síndromas de Libertação), e invertidos (Tabes, Polineurites, etc.).

b) Variações quantitativas - A diminuição ou abolição dos reflexos profundos ocorre nas lesões do arco reflexo elementar (neurites, polineurites, plexites, radiculites, poliomielites), Tabes, Molestia de FrIEDREICH, secção transversa da medula ( $1 .^{\mathrm{a}}$ fase), grandes hipertensões cranianas, miosites e miopatias avançadas, doenças gerais graves, caquéticas e adinâmicas, etc. A arreflexia congênita é raramente observada.

A exaltação dos reflexos profundos é principalmente observada nas lesões da via piramidal, por determinarem a libertação do neurônio motor periférico (Síndroma de libertação): Hemiplegias, Esclerose em placas, Esclerose Lateral amiotrófica, mielites, compressões medulares, etc. A hiper-reflexia profunda ainda pode ser encontrada nas afecções febris (febre tifoide, pneumonia, reumatismo), na Raiva, no Tétano, nas Intoxicações (estricnina, atropina, tebaina,), etc.

Alterações dos reflexos cutâneos - A diminuição, ou a abolição, dos reflexos cutâneos é verificada nas lesões do arco reflexo elementar (neurites, radiculites, etc.), bem como nas lesões da via piramidal (Hemiplegias e Paraplegias piramidais, Esclerose em placas, Esclerose Lateral Amiotrófica, etc.). Nesta ultima eventualidade, entretanto, um reflexo, o cutâneo-plantar, não se apresenta abolido, mas invertido: a excitação cutâneo-plantar determina, então, a extensão lenta, "majestosa", do grande artelho, acompanhada, ou não, da extensão, ou da abertura em leque, dos demais dedos (*). Essa resposta constitue o classico "Sinal de BABINSKy", caraterístico das lesões piramidais.

2 - Os reflexos tônicos, isto é, aqueles que determinam como resposta uma contração muscular lenta, firme e persistente, resultante de alterações do tono muscular, compreendem:

a) os reflexos labirínticos, importantes na manutenção do equilibrio e provocados pela excitação otolítica;

b) os reflexos cervicais de MAGNus-KLEIN, encontrados em casos clínicos análogos à Rigidez Descerebrada dos animais, em certas síndromas piramidais, na Síndroma de Little, etc...

(Pesquisa: fazendo-se a rotação passiva da cabeça para um dos lados, observa-se a flexão tônica do membro superior do lado oposto - membro "cranial" - e a extensão do membro superior do mesmo lado - membro "facial");

c) os reflexos de postura, de FoIx-ThevenARD, de naturesa proprioceptiva e tambem denominados "reflexos de fixação", porisso que a contração tônica muscular, produzida quando se coloca passi-

(*) O S. de BABINsky pode ser cbtido não só pela excitação cutâneo-plantar, mas ainda pelas variantes de Oppenheim (atrito sobre a crista da tibia), Schaefer (compressão do tendão de Aquiles), Gordon (compressão das pantorrilhas), Austregesilo-ESPosẼ (pinçamento da face anterior da coxa), etc.. São também sinais de significado equivalente ao S. de BABINSKY, o de Rossolimo (flexão dos dedos pela percussão ligeira e rápida de sua face inferior, ou do sulco metatarso-falagiano) e de MENDEL-BECHTEREW (flexão plantar dos 4 ultimos dedos pela percussão do cuboide). 
vamente um segmento de membro numa determinada atitude, tende a fixar o segmento na posição que lhe foi imposta. Pesquisam-se principalmente ao nivel das articulações do tornozelo (flexão passiva do pé, rápida e forte) e do punho (flexão passiva da mão sobre o antebraço); em consequência da contração muscular tônica então produzida, salientam-se os tendões correspondentes, conservando a articulação a atitude na qual fora passivamente colocada.

Os reflexos locais de postura apresentam-se exagerados em certas afecções do Sistema Extra-piramidal (Mal de Parkinson, Síndromas Parkinsoneanas post-encefalíticas, Molestia de Witson, Atetose Dupla) e diminuidos ou abolidos nas lesões da via piramidal, nas do arco reflexo elementar, na Tabes e nas afecções do cerebelo.

3 - Os reflexos vegetativos ou Simpáticos, que se realisam, total, ou parcialmente, na_esfera do Sistema Nervoso Autônomo, informam-nos sobre o estado do "Tono vegetativo". Os principais são os seguintes: R. óculo-cardíaco, pilo-motor, cutâneo-vaso motor (dermografismos), víscero-motores, córneo-lacrimal, escrotal ou dartoico, vesical, retal, uterino, genital, anal interno etc...

B) Clono: Série de contrações musculares rítmicas, obtidas quando se faz a distensão brusca e passiva de um tendão; têm duração variavel, subordinada ao tempo em que se mantem a distensão do tendão. Clono do pé, da rótula, da mão, do masséter. Distingui-1o do "falso clono" observado nos indivíduos emotivos, nos histéricos, etc.

C) Trepidações Epileptoides: Movimentos rítmicos que acometem um membro todo, aparecendo por ocasião da pesquisa de certos reflexos (patelar, por exemplo) ou à realisação de algum movimento (durante a marcha, principalmente).

D) Automatismos: Reações motoras involuntárias, consequentes a excitações cutâneas ou profundas (BABINSKy e JARKowsKy). A excitação do dorso do pé, por exemplo, pelo beliscamento, atrito, etc. determina, em casos de lesões piranidais, uma "triplice flexão", (do pé, perna e coxa), involuntária, que persiste durānte alguns segundos. Tais reações são tambem denominadas, impropriamente, "reflexos de defesa". As principais manobras reveladoras do automatismo são: 1) M. de BABinsky: beliscamento do dorso do pé. 2) M. de Pierre Marie-Foix: flexão forçada e demorada dos quatro ultimos artelhos. 3) Somação das excitações (Prof. A. Tolosa): percussões repetidas na base dos artelhos.

E) Sincinesias: Movimentos involuntários, e muitas vezes inconcientes, que se produzem no lado paralizado de um hemiplegico, quando são executados movimentos voluntários no lado são. A fisiopatologia das sincinesias é complexa e não se acha ainda perfeitamente esclarecida; são fenômenos observados, entretanto, principalmente nas lesões piramidais, caraterizando, ao lado da hiper-reflexia profuinda, sinreflexias, clono, trepidações e automatismos, o quadro da "Síndroma de Libertação". 


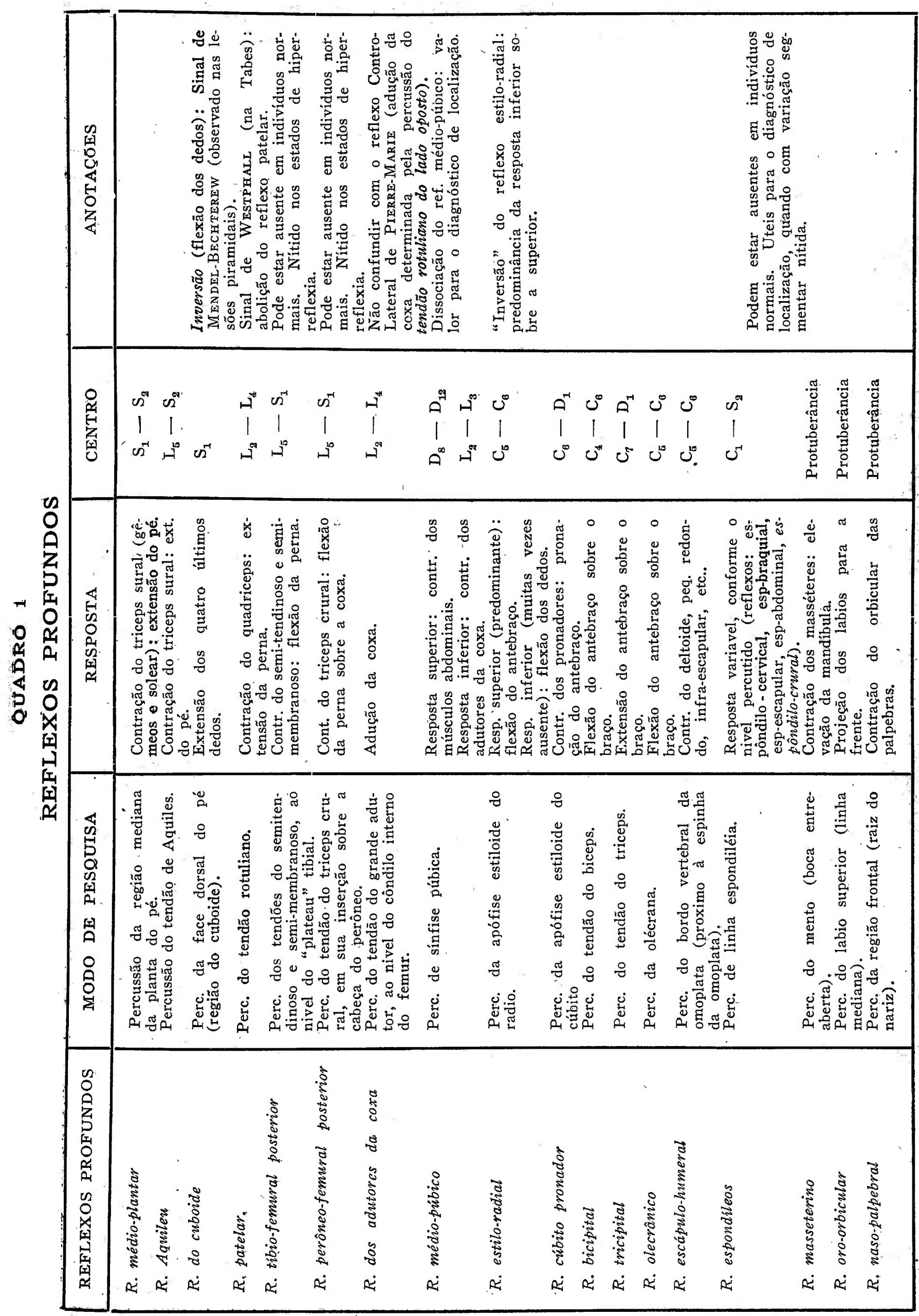




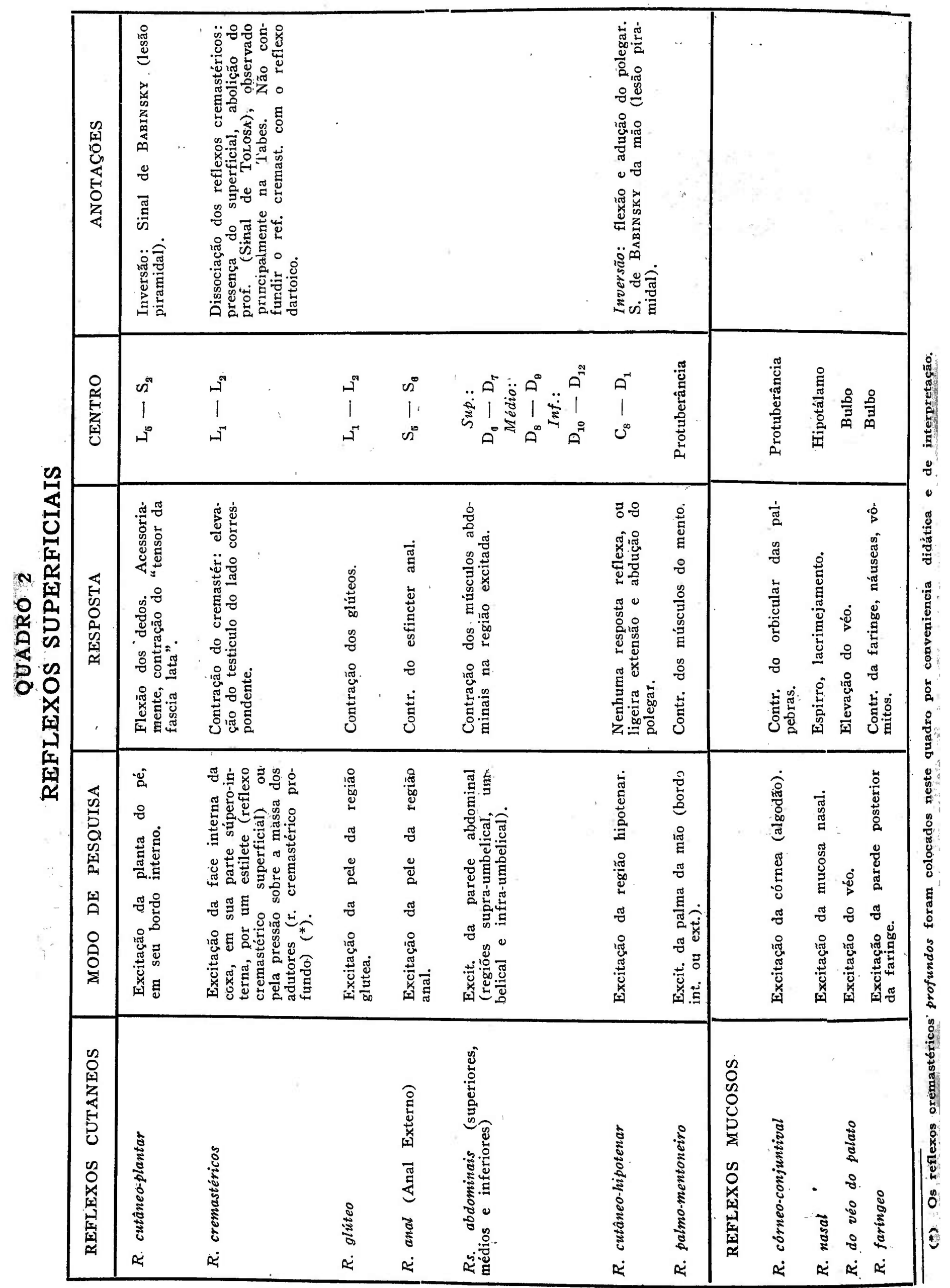


Segundo P. Marie e Forx, as sincinesias clasificam-se em:

1 - Sincinesia global: reforço da contratura dos membros paralizados e, consequentemente, exagero da atitude caraterística (flexão do membro superior, extensão do membro inferior), quando o paciente executa, com esforço, um movimento do lado são (aperto de mão, por exemplo).

2 - Sincinesia de imitação: no lado paralizado produzem-se movimentos involuntários que imitam os realizados, voluntariamente, no lado são.

3 - Sincinesia de coordenação: produzem-se no lado paralizado movimentos involuntários, por ocasião da execução de movimentos voluntários sinergicos. Varias manobras evidenciam as Sinc. de coordenação: Provas de Raimiste, de Cacciapuoti, de Hoover, de Neri, fenômeno do tibial anterior de Strumpell, etc...

\section{4 - SENSIBILIDADE}

O exame da sensibilidade, exigindo do clinico habilidade e paciencia e, por outro lado, subordinando-se ao estado de espirito, à mentalidade e ao gráo de cultura do paciente, constitue uma das etapas mais dificeis do exame neurológico. Necessita ser conduzido de acordo com técnica rigorosa, sob pena de não merecerem fé os resultados obtidos.

Dependendo as conclusões do exame diretamente das informações prestadas pelo paciente, a colaboração deste ultimo é, evidentemente, indispensavel. Por isso, proceder ao exame oportunamente, quando se encontra disposto o paciènte; ; informa-lo, ainda, sobre a importancia da investigaçấo da sensibilidade para a elucidação do diagnóstico e, consequentemente, para a orientação terapêutica. Explicar de antemão ao doente as manobras a serem executadas, afim de que as respostas sejam suficientemente precisas.

Durante o exame, o doente permanecerá de olhos vendados, para que não acuse as respostas sob a influencia do controle visual. Deverá achar-se desnudo, afim de facilitar o estudo comparativo da sensibilidade nas diferentes regiões do corpo. A exploração processarse-á sempre de maneira metódica e comparativa, iniciando-se, de preferencia, em regiões nas quais se presume estar conservada a sensibilidade.

Saber interrogar o paciente, evitando o emprego de quaisquer palavras capazes de sugestiona-lo. Melhor será, ainda, o doente assinalar as excitações praticadas pelo clínico independentemente de qualquer interrogatorio. A título de controlar a sinceridade das respostas, fazer, de quando em quando, perguntas ao paciente que não correspondam às excitações praticadas. 
Não prolongar demasiadamente o exame, realizando-o, si necessario, em sessões diversas, cada uma das quais não deverá ultrapassar 20 ou 30 minutos; evitar-se-ão, com essa prática, respostas contraditorias e inexatas, motivadas na maioria das vezes pela fadiga e falta de atenção do paciente.

Reproduzir, finalmente, em esquemas apropriados (gráficos da distribuição sensitiva, radicular ou periférica), as áreas de sensibilidade perturbada; para a delimitação exata destes territorios, muitas vezes, vários e repetidos exames serão necessários.

\section{FORMAS DA SENSIBILIDADE}

I - Sensibilidade Especial ou Sensorial - Visão, Audição; Olfação e Gustação.

II - Sensibilidade Geral, que compreende a S. Superficial e a S. Profunda.

A Sensibilidade Superficial abrange a S. Tátil, pesquisada por meio do algodão ou de um pincel, a $S$. à dor, pesquisada por meio de uma agulha ou alfinete e a Sensibilidade térmica, pesquisada por meio de dois tubos, um contendo água quente (temperatura não superior a $50^{\circ}$ C.) e outro com água gelada.

A Sensibilidade profunda compreende a $S$. Profunda conciente (Noção das atitudes segmentares, sensibilidade visceral, óssea, etc.) e a S. Profunda Inconciente (relacionada ao Tono, Equilíbrio e Coordenação).

São as seguintes as formas da Sensibilidade profunda conciente:

a) S. Segmentar ou Batiestésica ou Artrestésica, que informa sobre as atitudes segmentares do corpo. E' pesquisada imprimindo-se movimentos passivos, delicados, às diferentes articulações (falangianas, tornozelos, joelhos, etc.), estando o paciente com a musculatura dos membros relaxados no máximo gráo possivel; o doente, com os olhos fechados, deverá indicar, precisamente, a posição que assumiram os segmentos deslocados.

b) S. Vibratoria, Óssea, Palestésica ou Sens. ao Diapasão Pesquisada por intermedio de um diapasão especial, que não produza som (Diapasão de 50-60 vibrações) ; será colocado sucessivamente nas diversas saliencias ósseas (maléolos, crista da tíbia, espinhas ilíacas, esterno, clavículas, olécrana, apófise estiloide do radio e cúbito, etc.), devendo o doente acusar as vibrações de acordo com a intensidade da excitação.

c) S. Visceral - determinada pela compressão de certos órgãos (testículos, traquéa, glândulas mamárias, etc.). 
d) S. Dolorosa à pressão profunda - Sensibilidade à pressão dos músculos (pantorrilhas, músculos da coxa, braço, etc.), nervos (cubital, ciático), tendões (t. de Aquiles e outros).

e).S. Barestésica ou Sensibilidade aos.pesos - pesquisada por meio de tubos que apresentam forma idêntica e pesos diferentes.

f) S. Estereognóstica - Pesquisada colocando-se na mão do paciente objetos familiares (moeda, lapis, etc.), que devem ser prontamente identificados. O não reconhecimento dos objetos constitue a astereognosia.

g) Localização e discriminação tátil - Pesquisada pelo Com passo de Weber, que informa sobre a distância mínima, abaixo da qual duas excitações cutâneas, aplicadas simultaneamente, não são mais percebidas como sensações distintas. Os "circulos de sensação" variam com a região examinada: Ponta da lingua, 1,2 mm.; labios, 4 a $5 \mathrm{~mm}$.; face palmar dos dedos, 2 a $3 \mathrm{~mm}$; espadua, 55 a $77 \mathrm{~mm}$., etc...

\section{DISTURBIOS DA SENSIBILIDADE}

Apurar, inicialmente, a existencia de perturb̄ações subjetivas da sensibilidade:

Dores (séde, irradiação, modo de aparecimento, condições quie a exaltam ou diminuem, naturesa e intensidade, duração, frequência), parestesias ou disestesia $\boldsymbol{s}_{\boldsymbol{S}}$ (sensações anormais não dolorosas, frequentes nos processos periféricos: formigamentos, ferroadas, agulhadas, sensação de corrente elétrica, de agua quente ou fria etc.) e distúrbios cenestésicos, perturbações da sensibilidade visceral (crises gástricas, entéricas, da Tabes).

Perturbações da Sensibilidade Obietiva - Representadas principalmente pelas Anestesias, Hipoestesias e Hiperestesias (supressão, diminuição e exaltação, respectivamente, da sensibilidade).

As Anestesias e Hipoestesias classificam-se: quanto à extensão, em generalisadas (todo o tegumento) e localisadas (anestesia regional, a. segmentar, a. insular, hemi-anestesia, etc.) ; quanto à distribuicãa anatomica, em radiculares e neuríticas (periféricas); quanto às formas de sensibilidade comprometidas, em anestesia total (quando todas as formas se acham interessadas) e anestesia parcial '(ou dissociada). Os principais tipos de Dissociações de Sensibilidade são os seguintes:

1 - Dissociação periférica da sensibilidade - Comprometimento da sensibilidade superficial (tátil, dolorosa, termica), conservação da sensibilidade profunda. Observada na Lepra e em certas neurites tóxica.

2 - Dissociação siringomiélica - Comprometimento das sensibilidades do1orosa e termica; conservação das sensibildades tátil e profunda. Observada na. Siringomielia, Hematomielia, Tumores intramedulares, certas lesões do Istmo do Encéfalo, etc.

3 - Dissociação tábida - Comprometimento da sensibilidade prófunda e, menos acentuadamente, da sensibilidade tátil; conservação das sensibilidades dolorosa e termica. Observada na Tabes, síndromas neuro-anêmicas, radículo-neurites graves, determinadas lesões do Istmo do Encéfalo, etc.

4 - Dissociação talâmica - Nas lesões do tálamo, observa-se hemianestesia, superficial e profunda, do lado oposto à lesão; na mesma região, dores espontâneas, muito intensas (causalgias). E' a "anestesia dolorosa", caraterística das lesões do tálamo. 
5 - Dissociação cerebral ou cortical - Comprometimento das sensibilidades mais diferenciadas, "cerebrais" (estereognóstica, discriminação do táto, barestésica), e conservação das sensibilidades elementares (s. dolorósa, termica). Observada nas lesões cerebrais, principalmente nas do lobo parietal.

Hiperestesias - Como as anestesias e hipoestesias, podem classificar-se em generalizadas ou localizadas, totais ou parciais; ocorrem geralmente nas neurites e polineurites, radiculites, meningites agudas, lesões talâmicas, intoxicações, etc....

Outras anomalias - "Perversões" da sensibilidade objetiva - são constituidas pelos erros de localização (sinestesias, aloquiria), retardo da percepção, poliestesia, retorno das sensações, metamorfose das sensações, etc.

\section{5 - PERTURBAÇÕES TROFICAS}

As perturbações da troficidade ocorrem em numerosas afecções do Sistema Nervoso, podendo manifestar-se na pele, fâneros, tecido célulo-gorduroso, músculos, óssos e articulações.

a) Perturbações tróficas, da pele e anexos - A mais importante perturbação trófica cutânea, o mal perfurante, carateriza-se por ser indolor. e apresentar evolução crônica, localizando-se na maioria das vezes na planta dos pés. Ocorre frequentemente na Lepra. Outras vezes, acha-se filiado à Tabes, à Siringomielia ou ao diabete.

Panarício analgésico (ou Panarício de Morvan): observado nas afecções em que são importantes os distúrbios da sensibilidade dolorosa, tais como Lepra e. Siringomielia.

Escáras de decúbito: ocorrem nas lesões nervosas graves, particularmente nas mielites agudas, localizando-se quasi sempre nas regiões sacra, glúteas e-trocanterianas, menos frequentemente nos calcanhares.

"Glossy-skin": Pele adelgaçada, lisa e brilhante, observada especialmente nasextremidades dos membros, em casos de Siringomielia, Lepra e certas neurites (do mediano, por exemplo).

Outras perturbações tróficas são representadas por modificações da pigmentação da pele (melanodermia, leucodermia), erupções vesiculosas (HERPEs ZoSTER), atrofias cutâneas, hiperqueratoses, esclerodermia, etc...

b) Perturbações dos Fâneros - Alterações dos pêlos (modificações do desenvolvimento e coloração, alopecias, hipertricose, etc.) e das unhas (irregularidades do desenvolvimento, deformaçã̃o, atrofia, queda, perturbações da pigmentação, etc...).

c) Perturbações tróficas musculares - Compreendem :

1 - Atrofias musculares - Amiotrofias protopáticas, quando determinadas por uma afecção primitiva dos músculos (Miopatias). Amiotrofias deuteropáticas, quando consequentes a uma causa nervosa primitiva: lesão das pontas anteriores da médula (Amiotrofia mielo- 
pática), das raizes anteriores (Amiotrofia radicular), ou dos troncos nervosos (Amiotrofia neurítica). O modo de início, a distribuição da amiotrofia, a existencia ou não de alterações elétricas e muitos outros elementos permitem estabelecer facilmente a distinção entre esses diversos tipos de atrofias musculares.

2 - Hipertrofias musculares - observadas na Molestia de Thomsen e em certas afecções do Sistema Extrapiramidal.

3 - Pseudo-Hipertrofias musculares - ocorrem nas miopatias e são devidas ao desenvolvimento do tecido gorduroso intersticial.

4 - Retrações fibro-tendinosas - Frequentes nas afecções do neurônio motor periférico, podem acarretar deformações pronunciadas dos pés, mãos, ètc...

d) Perturbações tróficas ósseas - Deformações ósseas (cifoescoliose na Siringomielia e Mal de FrIEDREIch, cifose no $\mathrm{Mal}^{\prime}$ de Potт, etc), osteoporose, fragilidade óssea, luxações, fraturas “espontâneas" (Tabes e Siringomielia), mutilações (formas avançadas de Lepra e Siringomielia), perturbações do crescimento ósseo (Poliomielite anterior aguda, Hemiplegia Cerebral Infaltil), etc.

e) Perturbações tróficas articulares - Osteo-artroses podem manifestar-se, precoce ou tardiamente, no decurso da Siringomielia e especialmente no da Tabes. Caraterizam-se pelo início súbito e desenvolvimento rápido, em geral desacompanhado de dor. Enormes deformações articulares produzem-se, condicionadas por lesões ósteo-articulares do tipo destrutivo, atrófico, ou produtivo, hipertrófico. Enquanto que as ósteo-artroses tábidas geralmente se localizam nos membros inferiores, as siringomiélicas ocorrem frequentemente nos superiores.

\section{6 - PERTURBAÇóes VASO-MOTORAS}

Geralmente condicionadas por distúrbios da esfera simpática, encontram-se na Doença de Raynaud, Eritromelalgia, Meningites, Paralisia Infantil, Siringomielia, Encefalite epidêmica, antigas Hemiplegias, endócrinopatias, etc.

Podem ser observados: dermografismos, eritêmas, cianose, síncopes e asfixias locais, distermias, edemas (Hemiplegias orgânicas; mão suculenta, na Siringomielia; edema agudo angio-neurótico, Síndroma de Quincke; trofoedema crônico, Síndroma de Meige, etc.).

\section{7 - NERVOS CRANIANOS}

Será de toda conveniência completar a observação neurológica realizando o exame em conjunto e sistematizado, dos pares cranianos. Transcrevemos, a propósito, o esquema referido por P. STEWART:

I..$^{\circ}$ par (Nervo Olfativo) - Olfação - Anosmia. Parosmia. 
II. ${ }^{o}$ par (Óptico) - Acuidade visual. Campo visual de um objeto em movimento ou imovel. Hemianopsia. Cegueira para as côres. Exame oftalmoscópico. Papilas.

III..$^{\circ}$ par (Óculo motor comum), IV.$^{\circ}$ (Patético) e VI. ${ }^{\circ}$ (Óculo motor Externo) - Pupilas: dimensões, forma, reação à luz (direta e consensual), reação à acomodação.

Movimentos oculares externos - Estrabismo - Diplopia - Nistagmos.

$V .{ }^{\circ} \operatorname{par}$ (Trigêmeo) - Sensibilidade da face, das mucosas bucal, nasal e conjuntival, sensação gustativa para os $2 / 3$ anteriores da lingua.

Moțilidade dos masséteres, temporais, pterigoidianos, etc.

VII. ${ }^{\circ}$ par (Facial) - Fibras sensitivas do Nervo Intermediario: Sensibilidade cutânea do meato externo e da membrana do tímpano; gosto nos $2 / 3$ anteriores da lingua (corda do tímpano).

Fibras motoras: músculos faciais. Nervo do estribo. Hiperacusia.

VIII. ${ }^{\circ}$ par (Auditivo) - a) Nervo coclear ou acústico: Exame do ouvido: exame do meato e da membrana do tímpano. Condução aérea e óssea. Campo da audição.

b) Nervo vestibular: Vertigem. Reflexo otolítico. Nistagmo calórico. . Teste do desvio.

IX..$^{\circ}$ par (Glossofaríngeo) - Gosto: terço posterior da lingua. Anestesia da faringe. Dificuldades na deglutição. Movimentos do véo do palato.

X..$^{\circ}$ par (Pneumogástrico ou Vago) - Palato: ramo lạríngeo. recurrente - exame laringoscópico, coração, respiração, digestão.

$X I .^{\circ}$ par (Espinhal) - Esterno-cleido-mastoideu e trapezio.

$X I I .^{\circ}$ par (Hipoglosso) - Motilidade da lingua e troficidade.

\section{$\mathrm{V}$ - EXAMES COMPLEMENTARES}

Ao lado do exame clínico, torna-se geralmente necessario, para maior esclarecimento do caso, o concurso de exames complementares. Impõem-se, assim, em grande número de vezes, os exames neuro. ocular e neuro-oto-rino-laringológico, procedidos por especialistas, e a solicitação dos seguintes exames: reações de Wassermann e de Kahn no sangue; exame do líquido céfalo-raquiano, retirado por punção sub-ocipital ou, nos casos de afecções dos orgãos contidos no ráquis, punção lombar; exame elétrico, para o diagnóstico das afecções do neurônio motor periférico principalmente; exame radiográfico do craneo, simples ou com meio de contraste (Ventriculografias, Pneumoencéfalografias, Arteriografias) e da coluna vertebral, simples ou, nos casos de bloqueio do canal raquiano, recorrendo ao lipiodol; exame hematológico, (contagem global e específica, dosagem de Hemoglo- 
bina e do suco gástrico (prova de Katsch-KALK) nas síndromas neuro-anêmicas, exame parasitológico das fezes, exame de urina, medida do metabolismo basal, biópsias, etc... (*)

\section{VI - DIAGNóSTICO}

Os dados colhidos pelo exame clínico e provas complementares permitirão estabelecer, geralmente com precisão, o diagnóstico do caso: Verificar-se-á si se trata de molestia "funcional" ou orgânica do Sistema Nervoso, estabelecendo, neste último caso, o diagnóstico anatômico (sede da lesão) e o diagnóstico etio-paitogênico da afecção. Desses elementos, dependerão o prognóstico e a conduta terapêutica adequada ao caso.

(*) Consultar, a propósito:

Contribuição oto-laringo-oftalmológica para o diagnóstico das molestias. nervosas. Professor Aderbal Totosa. Rev. de Biologia e Medicina, vol. 1, n.o 4, Julho - Agosto de 1940.

Perturbações oculares em algumas molestias nervosas. Prof. Aderbal Tolosa. Boletim da Soč. de Med. e Cirurgia de S. Paulo - N.o especial da Semana Oftalmo-Neurológica, 1927.

Interpretação dos exames do líquido céfalo-raquiano - Prof. Aderbal Tolosa. Rev. Clinica de S. Paulo, Setembro de 1938.

O líquido céfalo-raquiano em clínica - Dr. Oswaldo Lange, 1938.

Ventriculografia nos tumores intra-cranianos - Dr. Carlos Gama. Rev. Soc. Reg. Med. e Cir. Taubaté, Janeiro de 1937.

Sistematização das ventriculografias - Dr. Carlos Gama. Rev. Ass. Paul. Med., Junho de 1937. 


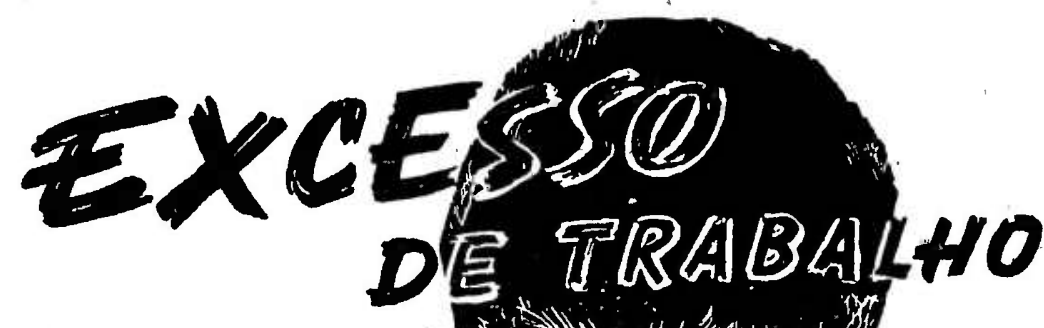

... exige alimento

- estimulo d̀ celula nervosa

\section{Nergofon}

hexapentanolcarboxil-hipotosfito de cálcio

encerrando $35 \mathrm{mg}$. de fósforo elementar por ampóla de 2 cmc. em combinaçäo organocálcica, exerce essa dupla ação de maneira rápida e duradoura.

AMOSTRAS

disposição dos

Srs. Médicos

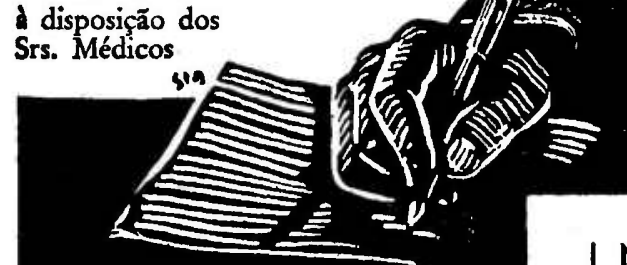

I NSTITUTO MEDICAMENTA ESTABELECIMENTO CIENTÍFICO - INDUSTRIAL FONTOURA \& SERPE • SÃO PAULO - BRASIL.
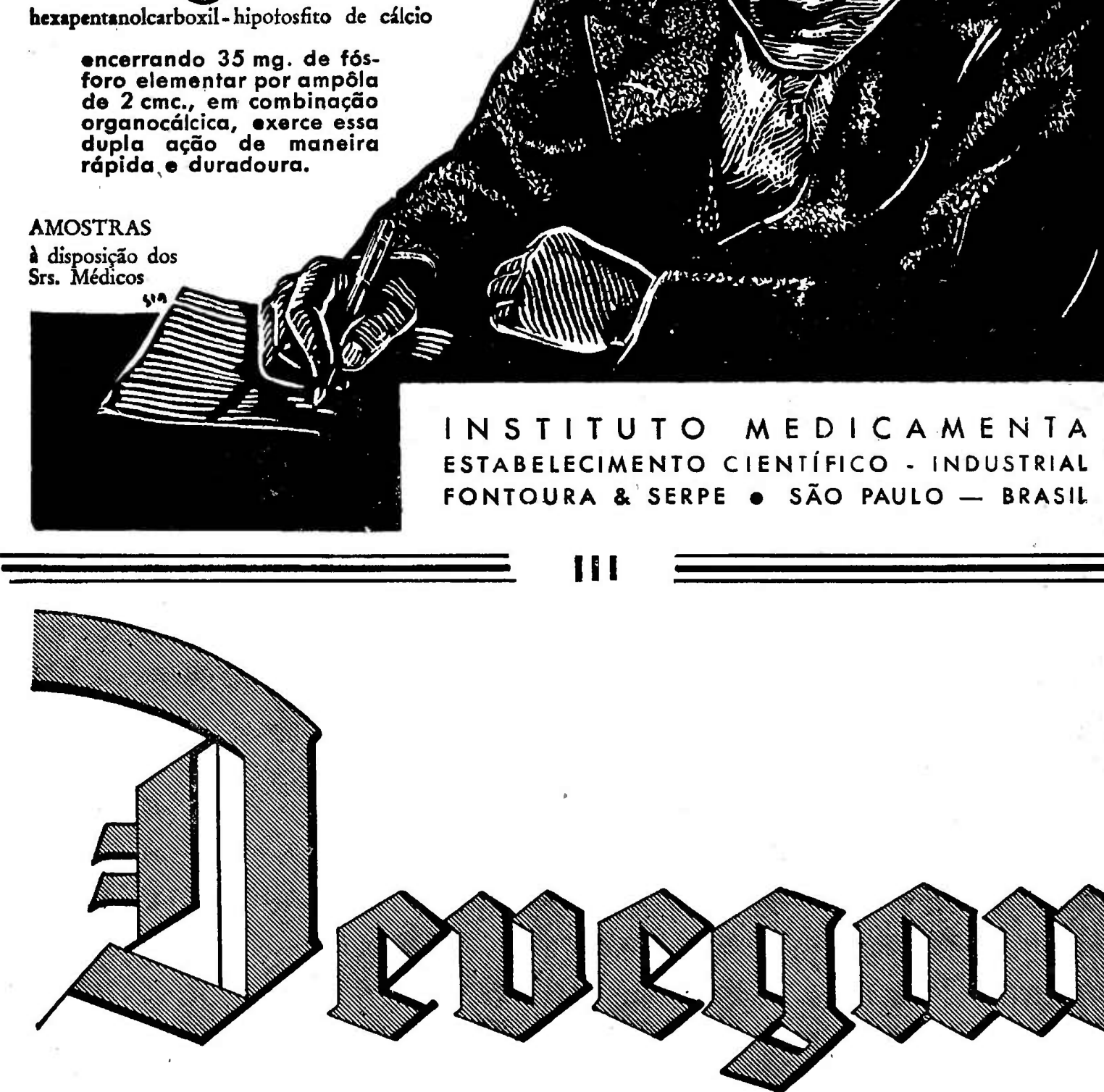

Para o tratamento dos fluxos vaginais de qualquer natureza, inclusive os frequentes e persistentes corrimentos produzidos pelos tricomonas.

Permite um tratamento bio-etiologico pelo favoravel reforçamento da fauna microbiana natural.

Embalagem original:

vidro de 30 comprimidos de $1 \mathrm{gr}$ 